\title{
Detection of Adhesion Encoding Genes, Antibacterial Susceptibility and Biofilm Formation of Uropathogenic Escherichia coli Isolated from Urinary Tract Infections in Children
}

\author{
Rezvan Goodarzi ${ }^{1}(D)$, Rasoul Yousefimashouf ${ }^{1}(\mathbb{D})$, Iraj Sedighi ${ }^{2}(D)$, Abbas Moradi $^{3}(D)$, \\ Fatemeh Nouri 4 (D), Mohammad Taheri ${ }^{5 *(D)}$
}

1. Dept. of Medical Microbiology, Faculty of Medicine, Hamadan University of Medical Sciences, Hamadan, Iran

2. Dept. of Pediatric, Faculty of Medicine, Hamadan University of Medical Sciences, Hamadan, Iran

3. Dept. of Community Medicine, Hamadan University of Medical Sciences, Hamadan, Iran

4. Dept. of Pharmaceutical Biotechnology, School of Pharmacy, Hamadan University of Medical Sciences, Hamadan, Iran

5. Dept. of Medical Microbiology, Faculty of Medicine, Hamadan University of Medical Sciences, Hamadan, Iran

\begin{tabular}{|c|c|}
\hline Article Info & ABSTRACT \\
\hline do) $10.30699 /$ jambs.30.e15083 & $\begin{array}{l}\text { Background \& Objective: Urinary tract infections (UTIs) are among the most } \\
\text { common infections in children worldwide and Escherichia coli is the main pathogen }\end{array}$ \\
\hline $\begin{array}{l}\text { Received: 2020/11/26; } \\
\text { Accepted: 2021/03/03; } \\
\text { Published Online: } 17 \text { Nov 2021; }\end{array}$ & $\begin{array}{l}\text { that can cause UTI. The current study aims to investigate the antibacterial } \\
\text { susceptibility pattern, biofilm production, and determine the frequency of afa and } \\
\text { sfa genes in E. coli strains isolated from pediatrics with UTI from } 2018 \text { to } 2019 \text { in } \\
\text { Hamadan, Iran. }\end{array}$ \\
\hline $\begin{array}{l}\text { Use your device to scan and read the } \\
\text { article online }\end{array}$ & $\begin{array}{l}\text { Materials \& Methods: In this cross-sectional study, } 112 \mathrm{E} \text {. coli strains were } \\
\text { collected from children with UTI. Disc diffusion method was performed to determine } \\
\text { antimicrobial susceptibility. The PCR was used to detect the existence of afa and sfa } \\
\text { genes. A microtiter plate assay was performed to test the biofilm production ability. }\end{array}$ \\
\hline $\begin{array}{l}\text { Dink } \\
\text { Article URL: Link }\end{array}$ & $\begin{array}{l}\text { Results: } 81(72.32 \%) \text { of the } 112 \mathrm{E} \text {. coli strains isolated from UTI samples were } \\
\text { positive for biofilm development }(22.2 \% \text { strong, } 33.3 \% \text { moderate, and } 44.4 \% \text { weak). } \\
\text { The } a f a \text { and } s f a \text { genes were detected in } 29.4 \% \text { and } 49.1 \% \text { of the isolates, respectively. } \\
\text { Most isolates were resistant to cephalothin }(76.79 \%) \text { and sensitive to imipenem and } \\
\text { meropenem }(100 \%) \text {. }\end{array}$ \\
\hline $\begin{array}{l}\text { Corresponding Information: } \\
\text { Mohammad Taheri, } \\
\text { Dept. of Medical Microbiology, } \\
\text { Faculty of Medicine, Hamadan } \\
\text { University of Medical Sciences, } \\
\text { Hamadan, Iran. } \\
\text { E-Mail: } \\
\text { Motaheri360@ gmail.com }\end{array}$ & $\begin{array}{l}\text { Conclusion: The afa and } s f a \text { genes have a significant correlation with strong } \\
\text { biofilm formation in uropathogenic E. coli (UPEC). } \\
\text { Keywords: Uropathogenic Escherichia coli, Drug Resistance, Biofilm, afa and sfa } \\
\text { genes, Urinary Tract Infection }\end{array}$ \\
\hline (c) $\underset{\mathrm{Br}}{\mathrm{BPC}}$ & ion. \\
\hline
\end{tabular}

\section{Introduction}

Urinary tract infection (UTI) in children is one of the most frequent infections, and it has a significant economic cost (1). Uropathogenic Escherichia coli (UPEC) is one of the most prevalent pathogens that cause UTI and asymptomatic bacteriuria in children $(2,3)$. It causes a variety of problems in children of all ages, but because of anatomical differences in the urinary system, it is more common in girls (4). The severity of a UTI is determined by bacterial virulence factors and human immunity. Fimbriae, toxins, and iron absorption systems are the most important factors of bacterial virulence that can play a role in biofilm formation (5). UPEC to bind to epithelial cell receptors can produce several adhesion types of $\mathrm{H}$ and $\mathrm{S}$ fimbriae $(6,7)$. S fimbriae, which interacts with sialic acid in the bladder epithelium and urethral ducts, is encoded by the $s f a$ gene $(8,9)$. Biofilm production is one of the pathogenic processes that allows $E$. coli to remain in the urinary system and colonize it more effectively (10). Bacterial biofilm is a cluster of bacteria encased in a polysaccharide matrix that lowers antibiotic sensitivity. They also participate in the interchange of food and genetic material such as plasmids from one bacterium to another, and the emergence of antibiotic resistance (11). Because of enhanced resistance to antimicrobials and the host immune system, the formation of microbial biofilms poses a significant obstacle to the progression of the illness (12). Antibiotic resistance is on the rise among members of the Enterobacteriaceae family, notably $E$. coli, in children all around the world. Antimicrobial resistance in $E$. coli decreases treatment options, 
increasing healthcare expenses and mortality (13). Antibiotic administration patterns in various geographical locations can have a role in the development of antibiotic resistance in that area (14).

Due to the high prevalence of UTI in children and the significance of biofilms in the development of this illness, the aim of current study was to explore the link between biofilm formation in isolated UPEC strains and its antibiotic resistance pattern in patients with UTI in Hamadan, Iran.

\section{Materials and Methods}

\section{Sample preparation}

In the current cross-sectional study, 112 E. coli strains isolated from pediatrics with UTI $\left(10^{5} \mathrm{CFU} / \mathrm{mL}\right.$ of urine $)$ referred to Besaat and Sina hospitals. Bacterial strains were isolated from November 2018 to April 2019. The subjects in this study were outpatients who had UTIs; bacterial growth of $E$. coli isolated from urine culture was judged positive. Exclusion criteria were the use of a urinary catheter, consumption of antibiotics during the previous two weeks, and a urinary tract disorder. Morphological and biochemical testing was used to confirm the specimens. They were incubated at $37{ }^{\circ} \mathrm{C}$ overnight and confirmed with biochemical differentiation tests. The bacterial isolates were stored at $-20^{\circ} \mathrm{C}(15)$.

\section{Antimicrobial Susceptibility Testing}

Antibiotic susceptibility was carried out via the KirbyBauer disk diffusion assay. All antibiotic discs were purchased from ROSCO, Denmark. The standard 0.5 McFarland microbial suspension was prepared according to CLSI 2018 for antimicrobial susceptibility testing.

Antimicrobial susceptibility tests were done on MullerHinton agar after the $0.5 \mathrm{McF}$ arland bacterial suspension was prepared. As a standard control, E. coli ATCC 25922 was applied. The antibiotic discs used in the study were Ciprofloxacin $(5 \mu \mathrm{g})$, Nitrofurantoin $(300 \mu \mathrm{g})$, Meropenem (10 $\mu \mathrm{g})$, Imipenem $(10 \mu \mathrm{g})$, Cephalothin $(30 \mu \mathrm{g})$, Cefotaxime (30 $\mu \mathrm{g})$, Nalidixic acid $(30 \mu \mathrm{g})$, Cefixime $(5 \mu \mathrm{g})$, Ceftriaxone (30 $\mu \mathrm{g}$ ) Cotrimoxazole (trimethoprim $1.25 \mu \mathrm{g}+$ sulfamethoxazole $23.75 \mu \mathrm{g})$, Amikacin $(30 \mu \mathrm{g})$ and Gentamicin $(10 \mu \mathrm{g})(\mathbf{1 5}, 16)$.

\section{Biofilm Formation}

Biofilm production ability in UPEC isolates was examined by the microtiter plate. The assay was performed in triplicate. E. coli isolates were prepared and incubated at $37{ }^{\circ} \mathrm{C}$ overnight. A $0.5 \mathrm{McF}$ arland standard microbial suspension was prepared; $200 \mu \mathrm{L}$ of was added to each well and incubated for additional 16-18 hours at $37^{\circ} \mathrm{C}$. Normal saline was used three times in the washing step, then to fix cells, $200 \mu \mathrm{L}$ absolute ethanol (96\%) was added to wells; the good contents were pulled after 15 minutes, and lets plate was dried at room temperature. The staining step was carried out by adding $200 \mu \mathrm{L}$ of $2 \%$ crystal violet for five minutes. After the color was removed, $200 \mu \mathrm{L}$ of 33 percent acetic acid was added to each well and incubated for 15 minutes at $37{ }^{\circ} \mathrm{C}$; the optical density was then recorded using an ELISA Plate Reader at a wavelength of $492 \mathrm{~nm}(17,18)$.

\section{DNA Extraction}

Total DNA extraction was performed using a boiling method. E. coli bacteria were first dissolved in $300 \mu \mathrm{L}$ of distilled water and boiled for 10 minutes at $95{ }^{\circ} \mathrm{C}$. Centrifugation was performed at $12,000 \mathrm{rpm}$ for 10 minutes. $100 \mu \mathrm{L}$ of supernatant is considered a DNA template. DNA concentration was checked through a nanodrop spectrophotometer. In the present study, PCR detected $a f a$ and $s f a$ genes. The specific primer sequences have been shown in Table 1 .

Table 1: Primer sequences and annealing temperature used for afa and sfa genes amplification

\begin{tabular}{|c|c|c|c|c|}
\hline Genes & Primer sequences & $\begin{array}{l}\text { Fragment } \\
\text { size (bp) }\end{array}$ & $\begin{array}{l}\text { Annealing } \\
\text { temperature }\end{array}$ & Reference \\
\hline afa & $\begin{array}{c}\text { F:5'-CGGCTTTTCTGCTGAACTGGCAGGC-3' } \\
\text { R:5'CCGTCAGCCCCCACGGCAGACC3' }\end{array}$ & $672 b p$ & 59 & 15 \\
\hline sfa & $\begin{array}{l}\text { F;5'-CTCCGGAGAACTGGGTGCATCTTAC-3' } \\
\text { R:5'-CGGAGGAGTAATTACAAACCTGGCA-3 }\end{array}$ & $410 \mathrm{bp}$ & 63 & 15 \\
\hline
\end{tabular}

\section{Polymerase Chain Reaction}

PCR reaction mixture was prepared in a total volume of $20 \mu \mathrm{L}$ including $10 \mu \mathrm{L}$ of master mix, $1 \mu \mathrm{L}$ of forward and reverse primer $(10 \mathrm{pmol} / \mathrm{L}), 1 \mu \mathrm{L}$ of DNA template, and $3.5 \mu \mathrm{L}$ of nuclease-free water. In the present study, standard strains harboring $a f a$ and $s f a$ genes were utilized as the positive control to validate the accuracy of each test. Gene amplification was done in a thermocycler (Bio-Rad, USA); the PCR program including initial denaturation, one cycle at $95^{\circ} \mathrm{C}$ for one minute, followed by 35 cycles; denaturation at $95{ }^{\circ} \mathrm{C}$ for 30 seconds; annealing at $59{ }^{\circ} \mathrm{C}$ and $63{ }^{\circ} \mathrm{C}$ for $a f a$, and $s f a$ genes respectively, for 45 seconds; extension, $72{ }^{\circ} \mathrm{C}$ one minute, and the final extension at $72{ }^{\circ} \mathrm{C}$ for 5 minutes (22). The PCR products were separated by electrophoresis on a $1 \%$ agarose gel (Merck Germany) and visualized using Gel Documentation (Uvitec, UK).

\section{Statistical Analysis}

SPSS Statistics version 17.0 was used to analyze the data (SPSS Inc., Chicago, III., USA). The chi-square and Fisher's exact tests were used to compare nominal variables represented as mean or frequency. Two-tailed probability was used and the $p$-values less than 0.05 were considered statistically significant. 


\section{Results}

The present study was performed on 112 E. coli strains in Hamadan from 2018 to 2019. The Age range of the children with UTI was one month to 12 years (mean 5.881). Regarding gender, 29 (25.9\%) and 83 (74.10\%) isolates were isolated from boys and girls, respectively.

Antibiotic susceptibility and resistance pattern (Figure 1) revealed that the highest resistance was found against Cephalothin $(76.79 \%)$, and the lowest resistance was observed to meropenem and imipenem $(0 \%)$. There was no significant association between gender and biofilm production $(p \geq 0.05)$. The results of microtiter plate method in our research indicated that $81(72.32 \%)$ E. coli strains isolated from UTI patients were biofilm producers. Based on OD, biofilm-production capacity was classified as high, moderate, or weak. Of the 81 biofilm-producing $E$. coli strains, $18(22.22 \%)$ were strong, 27 (33.33\%) moderate, and $36(44.44 \%)$ weak biofilm producers. Nevertheless, $31(27.67 \%)$ isolates did not show biofilm formation. The production of strong biofilms and $s f a$ genes were found to have a substantial relationship $(p<0.0001)$.

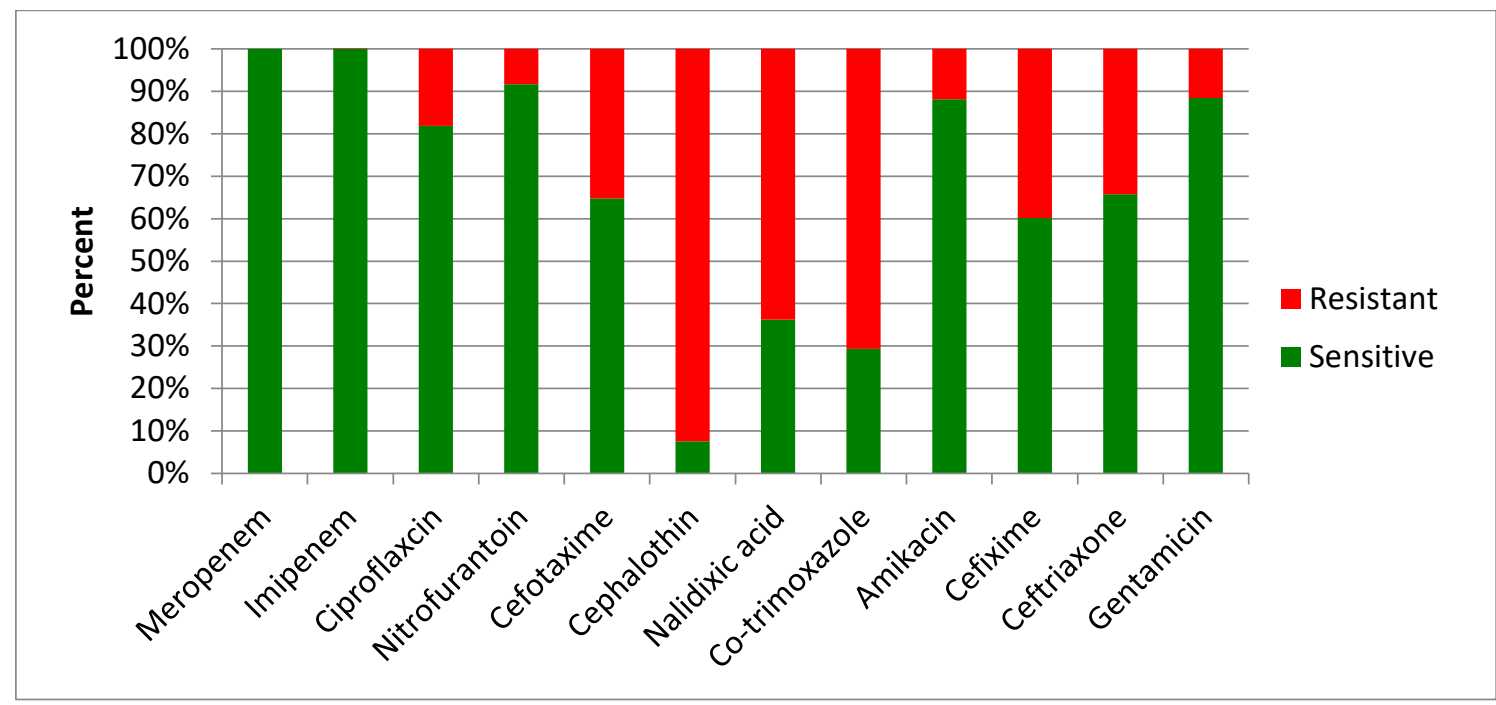

Figure 1: Antibiotic susceptibility testing of uropathogenic Escherichia coli isolates.

In the current study, the relationship between biofilm production and antibiotic resistance in antibiotics such as Nitrofurantoin and Cefotaxime was statistically significant $(p<0.05)$. Nevertheless, the relationship between biofilm production and other antibiotics was not statistically significant $(p \geq 0.05)$.

Regarding the frequency of virulence genes in $112 \mathrm{E}$. coli isolates by PCR, 33 strains $(29.4 \%)$ harbored afa gene, and $55(49.1 \%)$ isolates carried the sfa gene. The results of PCR amplification of afa and $s f a$ gene in UPEC isolates are represented in Figures 2 and 3, respectively. There was a statistically significant $(p<0.039)$ relationship between MDR and $a f a$ gene frequency. Even though there is no significant relationship between MDR and biofilm production $(p \geq 0.05)$.

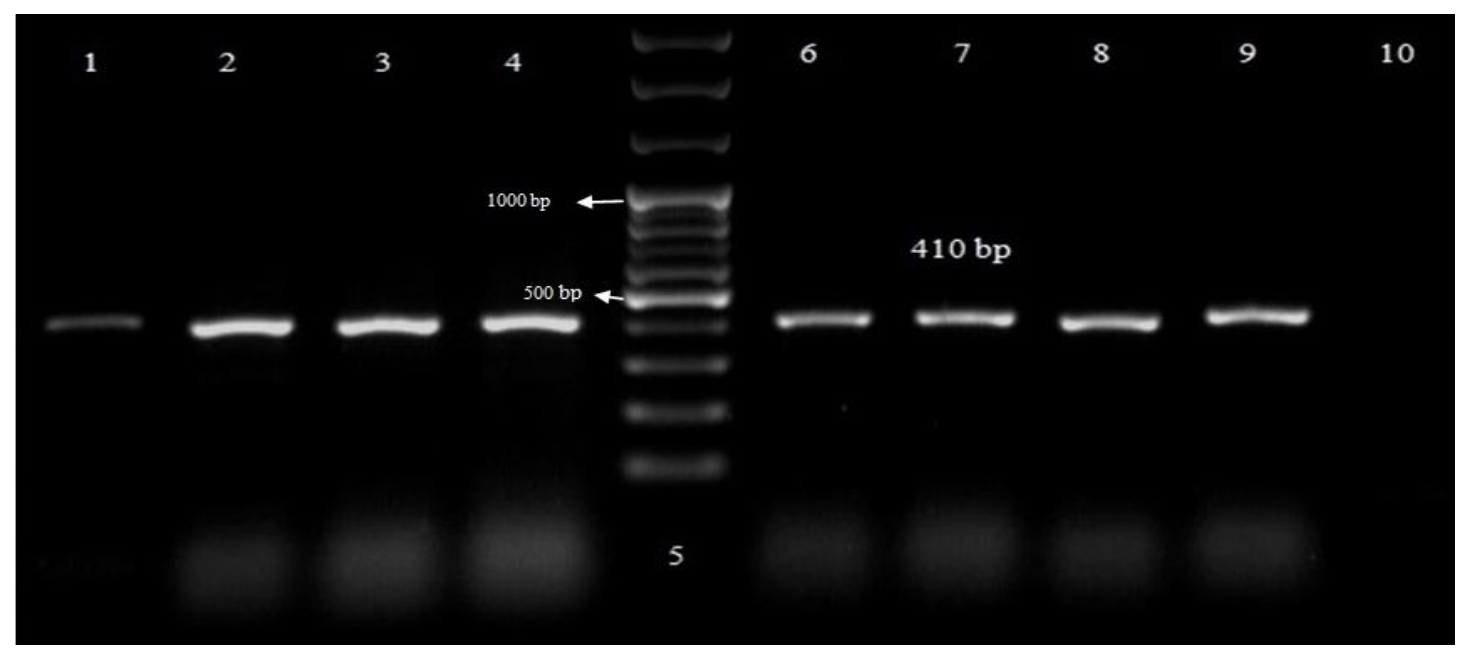

Figure 2: PCR amplification of afa gene in UPEC isolates. DNA Ladder (50 - 1000 bp); Lane 1, positive control; Lanes 2-4 and 6-9, PCR product from afa gene; Lane 10, negative control. 


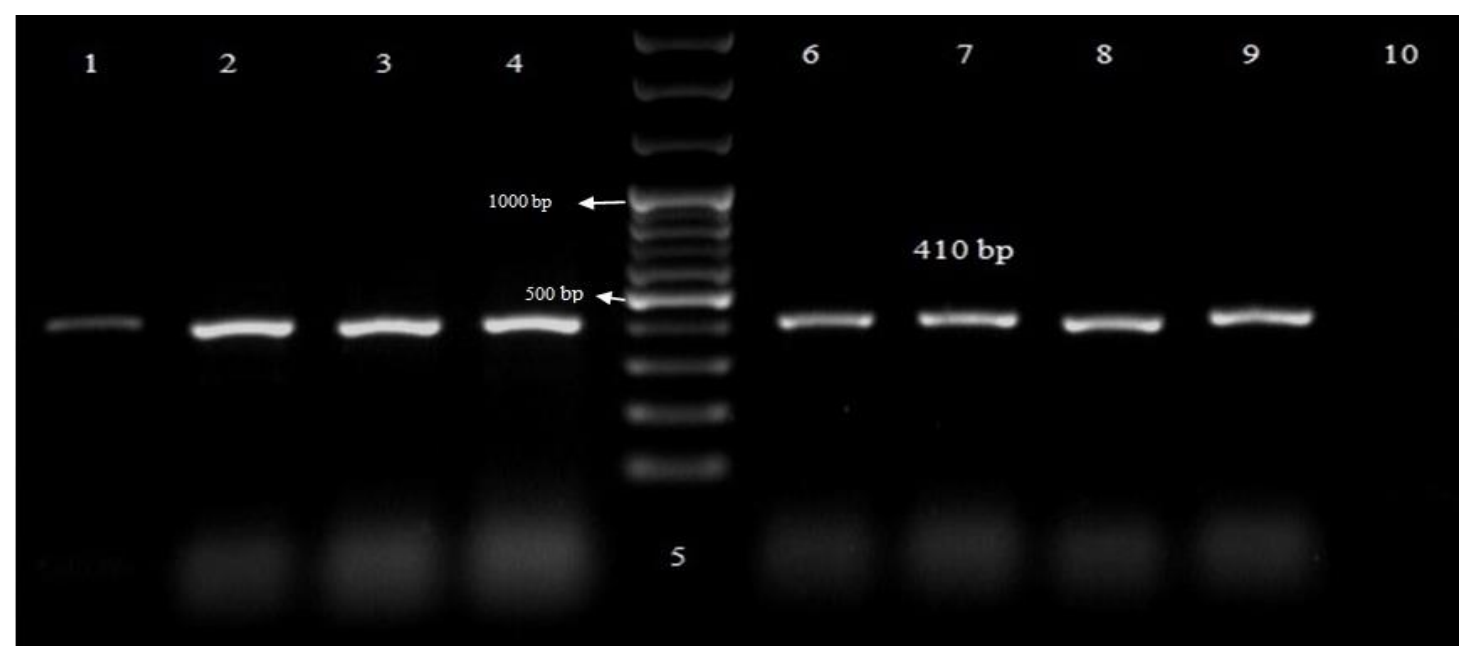

Figure 3: PCR amplification of sfa gene in UPEC isolates. Lanes 1-4 and 7-9, PCR product from sfa gene; DNA Ladder (50 1000 bp); Lane 6, positive control; Lane 10, negative control.

\section{Discussion}

Among the bacteria that cause urinary tract infections, E. coli is one of the most significant and common agents in children. In the current study, the frequency of UPEC in girls was higher than in boys, which could be attributed to female urinary tract anatomical conditions (19). This result contrasts with the findings of a study by Sedighi et al., i.e., the sensitivity of Imipenem (96.7\%). Susceptibility to Imipenem was expected to decline over time in this study. In recent years, increased sensitivity can be attributed to various protocols in studies and other antibiotic disks $(20,21)$.

According to overuse of antibiotics, such as Cotrimoxazole, it is shown that UPEC bacteria were resistant to Cotrimoxazole is increasing from 2000 to 2010, so that $6.3 \%$ increasing rate was reported (10). This increase in antibiotic resistance in this study could be attributed to excessive consumption of antibiotics, food intake from antibiotic-containing animals, the transmission of resistance isolates between individuals, self-medication, and non-compliance with conventional antibiotics $(16,17)$. It is believed that microbial adherence is the main critical stage involved in the pathogenicity of $E$. coli to the uroepithelial cells. The fimbriae handle this connection and colonization $(22,23)$. The investigations of $\mathrm{P}, \mathrm{S}, \mathrm{f1}$ s fimbriae and understanding microbial pathogenesis could assist physicians in predicting infection management. To determine the prevalence of virulence factors in E. coli, several molecular studies were conducted $(20,24)$.

Biofilm formation plays a key role in the increment of nosocomial infections and UTI in children. The literature review showed that biofilm-forming bacteria are responsible for more than $50 \%$ of bacterial infections $(2$, $25)$. In the present study, of the 81 biofilm-producing $E$. coli strains, $18(22.2 \%)$ were strong, 27 (33.3\%) moderate, and $36(44.4 \%)$ weak biofilm producers. According to a study by Kiehlbauch et al., 18\%, 25\%, and $56 \%$ of $E$. coli strains produced strong, moderate, and weak biofilms, respectively (24). Based on the study by Poursina et al., $80 \%$ of all UPEC isolates were biofilm producers, of which $29 \%, 34 \%$, and $17 \%$ had strong, moderate, and weak biofilm-producing ability, respectively (26). However, in our study, the frequency of biofilm formation is $22.2 \%$ strong, $33.3 \%$ moderate, and $44.4 \%$ weak; that this difference can be due to different geographical regions. Boroumand et al. reported that $75.38 \%$ of E. coli strains were biofilm producers (27). This high frequency can be due to genetic factors in the bacteria, and the use of certain groups of antibiotics. In Zamani study, among E. coli strains 36\%, 48\%, and 10\% showed high, moderate, and weak biofilm production, respectively and the rest of them were non-biofilm producers (28). Mittal et al. reported that $13.5 \%$ of $E$. coli were biofilm producers (29). Ponnusamy et al. recognized all isolated strains as biofilm-forming bacteria, with $6.6 \%$, $80.8 \%$, and $14.14 \%$ creating strong, moderate, and weak biofilms, respectively (30). Besides, Neupane et al. reported an increase in biofilm production among $51.92 \%$ E. coli strains using Congo Red Agar CRA (35). In a study by Ren et al., the biofilm development of $116 \mathrm{E}$. coli strains was examined. Biofilm was formed by $41.3 \%$ of the strains. $16.4 \%, 18.1 \%$, and $6.8 \%$ formed weak, moderate, and strong biofilms, respectively (31). Variation in biofilm formation outcomes could be attributable to geographic disparities in low sanitation, varied antibiotic resistance, and different origin of isolates in patients with urinary tract infections. According to our results, the frequency of $a f a$ and $s f a$ adhesive genes in $E$. coli were $24.9 \%(n=33)$ and $49.1 \%(n=55)$, respectively. In the current study, high frequency related to $\mathrm{S}$ fimbriae of $E$. coli indicated the importance of this virulence factor in the development of UTI. Furthermore, the prevalence of fimbriae $\mathrm{S}$ suggested that this factor was a fimbria requirement for adhesion and colonization $E$. coli in UTI $(22,32)$. Several similar studies have been done in different parts of the world, the results of which are different and can be due to differences in geographical areas, how antibiotics are prescribed, and the genetics of the disease-causing microorganisms $(28,33,34)$. The current study results showed that strains isolated from 
biofilm structure revealed a significant incidence of $a f a$ and $s f a$ genes. The afa and $s f a$ genes were found in $92.85 \%$ and 85.71 percent of high biofilm-producing isolates. The results of our study indicated that $s f a$ gene in UPEC has a substantial connection with high biofilm development (Pvalue < 0.0001). In this study, the frequency of afa and sfa adhesion genes were $29.4 \%$ and $49.4 \%$ respectively, which showed the important role of adhesins in UTI pathogenesis. $\mathrm{S}$ fimbria as a virulence factor in UPEC isolates can bind to the epithelial cells of the urinary tract system in humans and is a pivotal parameter in the biofilm production of UPEC strains $(31,35)$.

Investigation of the frequency of genes involved in bacterial adhesion can be effective in identifying and changing the medical approach. The monitoring of genes that are directly related to biofilm formation and antibiotic resistance can help researchers and physicians in the prevention, control, and treatment of infectious diseases.

\section{Conclusion}

The afa gene was shown to be more prevalent than $s f a$ in $E$. coli strains. Strong biofilm development was linked to both the afa and $s f a$ genes. Furthermore, the biofilm formation rate was higher in antibiotic-resistant $E$. coli strains than in antibiotic-susceptible bacteria. To avoid the establishment of multi-drug resistant bacteria, it is recommended that UTI in Hamadan be treated with Imipenem or Meropenem, based on the antibiotic resistance pattern. Other virulence factors involved in biofilm formation in $E$. coli that cause UTI should be investigated. Amikacin, Gentamicin, and Nitrofurantoin antibiotics can additionally be suggested to treat UTI as an empirical prescription in this geographical area. In this study, it was also found that $s f a$ gene has a critical role in the pathogenesis of $E$. coli isolated from urinary tract infections in children.

\section{Acknowledgments}

We are so thankful to Besat Hospital, Hamadan, Iran for sample preparation.

\section{Ethical considerations}

This study was approved by the ethics committee of Hamadan University of Medical Sciences, Hamadan, Iran (Ethical No: IR.UMSHA.REC.1397.360).

\section{Funding and Support}

The present study was supported by Hamadan University of Medical Sciences, Hamadan, Iran, financially supported the study (Grant No. 9706063298).

\section{Conflict of Interests}

The authors declare no conflict of interest.

\section{References}

1. Aljindan R, Alsamman K, Elhadi N. ERIC-PCR genotyping of Acinetobacter baumannii isolated from different clinical specimens. Saudi J Med Med Sci. 2018;6(1):13. [DOI:10.4103/sjmms.sjmms_138_16] [PMID] [PMCID]

2. Kosari F, Taheri M, Moradi A, Hakimi Alni R, Alikhani MY. Evaluation of cinnamon extract effects on clbB gene expression and biofilm formation in Escherichia coli strains isolated from colon cancer patients. BMC cancer. 2020;20(1):18. [DOI:10.1186/s12885-020-06736-1] [PMID] [PMCID]

3. Movahedi M, Zarei O, Hazhirkamal M, Karami P, Shokoohizadeh L, Taheri M. Molecular typing of Escherichia coli strains isolated from urinary tract infection by ERIC-PCR. Gene Rep. 2021;23:101058.

[DOI:10.1016/j.genrep.2021.101058]

4. Schembri MA, Kjaergaard K, Sokurenko EV, Klemm P. Molecular characterization of the Escherichia coli FimH adhesin. J Infect Dis. 2001;183(Supplement_1):S28-S31. [DOI:10.1086/318847] [PMID]

5. Madison B, Ofek I, Clegg S, Abraham SN. Type 1 fimbrial shafts of Escherichia coli and Klebsiella pneumoniae influence sugar-binding specificities of their FimH adhesins. Infect Immun. 1994;62(3):843-8. [DOI:10.1128/iai.62.3.843848.1994] [PMID] [PMCID]

6. Tohidi B, Rahimmalek M, Arzani A. Essential oil composition, total phenolic, flavonoid contents, and antioxidant activity of Thymus species collected from different regions of Iran. Food Chem. 2017;220:153-61. [DOI:10.1016/i.foodchem.2016.09.203] [PMID]

7. Galotto M, De Dicastillo CL, Torres A, Guarda A. Thymol: Use in antimicrobial packaging. Antimicrobial Food Packaging: Elsevier; 2016. p. 553-62. [DOI:10.1016/B978-0-12-8007235.00045-0]

8. Humphries RM, Ambler J, Mitchell SL, Castanheira M, Dingle T, Hindler JA, et al. CLSI methods development and standardization working group best practices for evaluation of antimicrobial susceptibility tests. J Clin Microbiol. 2018;56(4). [DOI:10.1128/JCM.01934-17]

9. Balighian E, Burke M. Urinary tract infections in children. $2018 \quad ; 39(1): 3-12$. [DOI:10.1542/pir.2017-0007] [PMID]

10. Sanchez GV, Master RN, Karlowsky JA, Bordon JM. In vitro antimicrobial resistance of urinary Escherichia coli isolates among US outpatients from 2000 to 2010. Antimicrob Agents 
Chemother.

2012;56(4):2181-3.

[DOI:10.1128/AAC.06060-11] [PMID] [PMCID]

11. Pourzare M, Derakhshan S, Roshani D. Distribution of uropathogenic virulence genes in Escherichia coli isolated from children with urinary tract infection in Sanandaj, Iran. Arch Pediatr Infect Dis. 2017;5(3):e41995. [DOI:10.5812/pedinfect.41995]

12. Tajbakhsh E, Ahmadi P, Abedpour-Dehkordi E, Arbab-Soleimani N, Khamesipour F. Biofilm formation, antimicrobial susceptibility, serogroups and virulence genes of uropathogenic E. coli isolated from clinical samples in Iran. Antimicrob Resist Infect Control. 2016;5(1):11. [DOI:10.1186/s13756-016-0109-4] [PMID] [PMCID]

13. Cassell GH, Mekalanos J. Development of antimicrobial agents in the era of new and reemerging infectious diseases and increasing antibiotic resistance. Jama. 2001;285(5):601-5. [DOI:10.1001/jama.285.5.601] [PMID]

14. Nouri F, Karami P, Zarei O, Kosari F, Alikhani MY, Zandkarimi E, et al. Prevalence of common nosocomial infections and evaluation of antibiotic resistance patterns in patients with secondary infections in Hamadan, Iran. Infect Drug Resist. 2020;13:2365. [PMID] [PMCID]

[DOI:10.2147/IDR.S259252]

15. Rahdar M, Rashki A, Miri HR, Ghalehnoo MR. Detection of pap, sfa, afa, foc, and fim adhesinencoding operons in uropathogenic Escherichia coli isolates collected from patients with urinary tract infection. Jundishapur J Microbiol. 2015;8(8). [DOI:10.5812/jjm.22647]

16. Tabasi M, Karam MRA, Habibi M, Yekaninejad MS, Bouzari S. Phenotypic assays to determine virulence factors of uropathogenic Escherichia coli (UPEC) isolates and their correlation with antibiotic resistance pattern. Osong Public Health Res Perspect. 2015;6(4):261-8. [DOI:10.1016/i.phrp.2015.08.002] [PMID] [PMCID]

17. Rivera-Sanchez R, Delgado-Ochoa D, Flores-Paz RR, García-Jiménez EE, Espinosa-Hernández R, Bazan-Borges AA, et al. Prospective study of urinary tract infection surveillance after kidney transplantation. BMC Infect Dis. 2010;10(1):245. [DOI:10.1186/1471-2334-10-245] [PMID] [PMCID]

18. Stepanović S, Ćirković I, Mijač V, ŠvabićVlahović M. Influence of the incubation temperature, atmosphere and dynamic conditions on biofilm formation by Salmonella spp. Food Microbiol. 2003;20(3):339-43. [DOI:10.1016/S0740-0020(02)00123-5]
19. Moez NM, Mashouf RY, Sedighi I, Shokoohizadeh L, Taheri M. Phylogroup classification and investigation the relationships between phylogroups and antibiotic resistance patterns of uropathogenic E. coli isolated from pediatric urinary tract infection. Gene Reports. 2020;20:100758.

[DOI:10.1016/j.genrep.2020.100758]

20. Jadhav S, Hussain A, Devi S, Kumar A, Parveen S, Gandham N, et al. Virulence characteristics and genetic affinities of multiple drug resistant uropathogenic Escherichia coli from a semi urban locality in India. PloS one. 2011;6(3):e18063. [DOI:10.1371/journal.pone.0018063] [PMID] [PMCID]

21. Sedighi I, Arabestani MR, Rahimbakhsh A, Karimitabar Z, Alikhani MY. Dissemination of extended-spectrum $\beta$-lactamases and quinolone resistance genes among clinical isolates of uropathogenic Escherichia coli in children. Jundishapur J Microbiol. 2015;8(7). [DOI:10.5812/jjm.19184v2]

22. Usein CR, Damian M, Tatu-Chitoiu D, Capusa C, Fagaras R, Tudorache D, et al. Prevalence of virulence genes in Escherichia coli strains isolated from Romanian adult urinary tract infection cases. J Cell Mol Med. 2001;5(3):303-10. [DOI:10.1111/j.1582-4934.2001.tb00164.x] [PMID] [PMCID]

23. Malekzadegan Y, Khashei R, Ebrahim-Saraie HS, Jahanabadi Z. Distribution of virulence genes and their association with antimicrobial resistance among uropathogenic Escherichia coli isolates from Iranian patients. BMC Infect Dis. 2018;18(1):572. [DOI:10.1186/s12879-018-34670] [PMID] [PMCID]

24. Kiehlbauch JA, Hannett GE, Salfinger M, Archinal W, Monserrat C, Carlyn C. Use of the National Committee for Clinical Laboratory Standards guidelines for disk diffusion susceptibility testing in New York state laboratories. J Clin Microbiol. 2000;38(9):3341-8.

[DOI:10.1128/JCM.38.9.3341-3348.2000] [PMID] [PMCID]

25. Kot B, Wicha J, Gruzewska A, Piechota M, Wolska K, Obrebska M. Virulence factors, biofilm-forming ability, and antimicrobial resistance of urinary Escherichia coli strains isolated from hospitalized patients. Turk J Med Sci. 2016;46(6):1908-14. [DOI:10.3906/sag-1508105] [PMID]

26. Poursina F, Sepehrpour S, Mobasherizadeh S. Biofilm formation in nonmultidrug-resistant Escherichia coli isolated from patients with urinary tract infection in Isfahan, Iran. Adv Biomed Res. 2018;7. [DOI:10.4103/abr.abr_116_17] [PMID] [PMCID] 
27. Boroumand M, Sharifi A, Manzouri L, Khoramrooz SS, Khosravani SA. Evaluation of pap and sfa genes relative frequency $\mathrm{P}$ and $\mathrm{S}$ fimbriae encoding of uropathogenic Escherichia coli isolated from hospitals and medical laboratories; Yasuj City, Southwest Iran. Iran Red Crescent Med J. 2019;21(8) :1-8.

28. Zamani H, Salehzadeh A. Biofilm formation in uropathogenic Escherichia coli: association with adhesion factor genes. Turk J Med Sci. 2018;48(1):162-7. [DOI:10.3906/sag-1707-3] [PMID]

29. Mittal S, Sharma M, Chaudhary U. Biofilm and multidrug resistance in uropathogenic Escherichia coli. Pathog Glob Health. 2015;109(1):26-9. [DOI:10.1179/2047773215Y.0000000001] [PMID] [PMCID]

30. Ponnusamy P, Natarajan V, Sevanan M. In vitro biofilm formation by uropathogenic Escherichia coli and their antimicrobial susceptibility pattern. Asian Pac J Trop Med. 2012;5(3):210-3. [DOI:10.1016/S1995-7645(12)60026-1]

31. Ren D, Zuo R, Barrios AFG, Bedzyk LA, Eldridge GR, Pasmore ME, et al. Differential gene expression for investigation of Escherichia coli biofilm inhibition by plant extract ursolic acid. Appl Environ Microbiol. 2005;71(7):4022-34. [DOI:10.1128/AEM.71.7.4022-4034.2005] [PMID] [PMCID]
32. Oliveira F, Paludo K, Arend L, Farah S, Pedrosa F, Souza E, et al. Virulence characteristics and antimicrobial susceptibility of uropathogenic Escherichia coli strains. Genet Mol Res. 2011;10(4):4114-25. [DOI:10.4238/2011.October.31.5] [PMID]

33. Choi C, Kwon D, Chae C. Prevalence of the enteroaggregative Escherichia coli heat-stable enterotoxin 1 gene and its relationship with fimbrial and enterotoxin genes in E. coli isolated from diarrheic piglets. J Vet Diagn Invest. 2001;13(1):26-9.

[DOI:10.1177/104063870101300106] [PMID]

34. Sasso MD, Culici M, Braga PC, Guffanti EE, Mucci M. Thymol: inhibitory activity on Escherichia coli and Staphylococcus aureus adhesion to human vaginal cells. JEOR. 2006;18(4):455-61.

[DOI:10.1080/10412905.2006.9699140]

35. Neupane S, Pant ND, Khatiwada S, Chaudhary R, Banjara MR. Correlation between biofilm formation and resistance toward different commonly used antibiotics along with extended spectrum beta lactamase production in uropathogenic Escherichia coli isolated from the patients suspected of urinary tract infections visiting Shree Birendra Hospital, Chhauni, Kathmandu, Nepal. Antimicrob Resist Infect Control. 2016;5(1):5. [DOI:10.1186/s13756-0160104-9] [PMID] [PMCID]

\section{How to Cite This Article:}

\section{Download citation:}

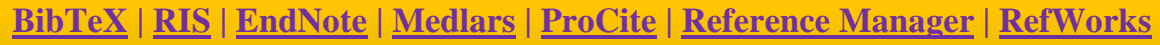

